eral centimetres in size, as well as small veins and veinlets. The porphyroblasts are mostly associated with tourmaline and garnet-mica-schists, while the veins and veinlets occur concordantly along widely spaced quartz veins. In two localities scheelite showings were found in folded metasediments.

The scheelite mostly has a bluish fluorescent colour, indicating a low Mo content. Locally, however, it occurs with a bright white fluorescent colour corresponding to a Mo content of the order of $0.5 \%$. In several localities in the amphibolites and metasediments the scheelite has a strong yellow fluorescent colour indicating a Mo content exceeding $5 \%$.

Acknowledgements. The author is grateful to Arent Zakarias Heilmann for his valuable assistance in the field, to E. Leonardsen, Geological Institute, University of Copenhagen, for X-ray determination of scheelite, and to Lissie Jans, Geological Institute, University of Aarhus, for drawing the field map. Financial support was received from Bikuben, Det Kongelige Grønlandsfond, Greenex A/S and Grønlandsbanken. A. A. Garde and P. W. U. Appel are thanked for advice and help.

\title{
References
}

Appel, P. W. U. 1983: Tungsten in the Godthåb area, West Greenland. Rapp. Grønlands geol. Unders. $115,59-63$.

Bridgwater, D., Keto, L., McGregor, V. R. \& Myers, J. S. 1976: Archaean gneiss complex of Greenland. In Escher, A. \& Watt, W. S. (edit.) Geology of Greenland, 18-75. Copenhagen: Geol. Surv. Greenland.

Geologisk Institut, Aarhus Universitet, DK-8000 Århus C, Denmark.

\section{Field observations around northern Godthåbsfjord, southern West Greenland}

\author{
Adam A. Garde
}

Mapping for the Fiskefjord map sheet was continued (Garde, 1984) for eight weeks in 1985. The author was first accompanied by F. Kalsbeek, and continued with H. K. Olsen and then J. Sangstad as assistants. The GGU cutter J. F. Johnstrup and a Jet Ranger helicopter on day charter from Nuuk provided logistic support.

Mapping was carried out in the eastern part of the map sheet area along the coasts of Godthåbsfjord and Qugssuk, and on the peninsula Ivnarssuaq towards the eastern map sheet boundary at $50^{\circ} 54^{\prime} \mathrm{W}$ (fig. 1 ).

The main lithological units consist of various supracrustal rocks equivalent to Malene rocks and large masses of late Archaean orthogneisses, which have intruded them. The mapping confirmed the tentative genetic and age relations between metadiorite, grey tonalitic gneiss, Taserssuaq tonalite and Qugssuk granite suggested by Garde (1984) and Garde et al. (in press) from neighbouring areas. The field work area in 1985 includes an important meta- 


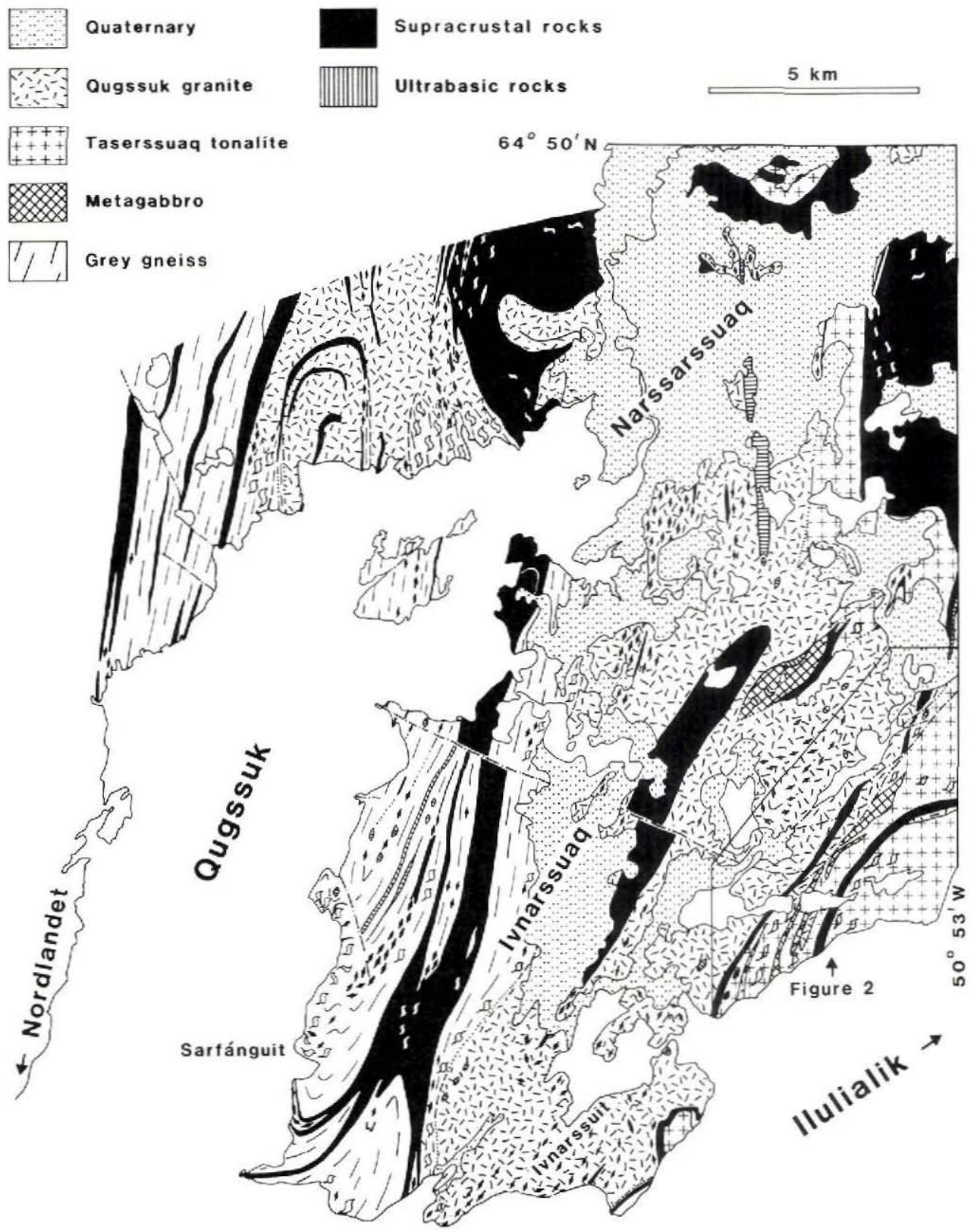

Fig. 1. Simplified geological map of the Ivnarssuaq peninsula between Qugssuk and Ilulialik.

morphic facies transition from granulite facies rocks on Nordlandet through rocks that have been retrograded from granulite to amphibolite facies, along the north-western coast of Qugssuk, to rocks at Ivnarssuaq which seem to have altogether escaped granulite facies metamorphism. 
The south-eastern part of the area is dissected by the Ataneq fault (fig. 2) which further north-east forms the north-western boundary of the Isua supracrustal belt, and which has been thought to be responsible for the geological contrast between mafic granulite facies gneisses on Nordlandet and intermediate to felsic gneisses in amphibolite facies around Nuuk, and on the islands in outer Godthåbsfjord. The mapping brought forward new information concerning the nature of this lithological and metamorphic change across outer Godthåbsfjord, and showed that a correlation across the Ataneq fault is possible which limits the lateral displacement across the fault to $4-5 \mathrm{~km}$.

\section{Supracrustal rocks}

In the north-eastern part of the Fiskefjord sheet mapped by the author in 1981 and 1983 , metasedimentary rocks form an insignificant part of the supracrustal unit. In its southward extension to Qugssuk and in western Ivnarssuaq there is a large proportion of (garnet-) mica schist and lesser sillimanite \pm garnet \pm cordierite schist. Besides amphibolite sensu stricto there are also fairly widespread intermediate (?andesitic) c. $1 \mathrm{~mm}$-grained plagioclase-biotite-hornblende metavolcanics, which are difficult to distinguish in the field from equally fine-grained but slightly more siliceous biotite schists of presumed clastic sedimentary origin. As a consequence of the moderate displacement across the Ataneq fault (see below) the north-north-east trending supracrustal rocks on western Ivnarssuaq can be correlated with the Malene supracrustals on Bjørneøen, Sadelø and Store Malene. Metasedimentary rocks are also significant members of the supracrustals in the latter two areas (Appel \& Garde, this volume; Olsen, this volume).

At Ivnarssuaq a highly disrupted ultramafic metadyke occurs around $64^{\circ} 39^{\prime} 30^{\prime \prime} \mathrm{N}$, $51^{\circ} 08^{\prime} \mathrm{W}$ within the supracrustals. It has a distinct bright green colour and spotted texture. At one locality the dyke is coherent over a length of $100 \mathrm{~m}$ and has preserved discordant relations to the host, which is here foliated metasediment that has been melted and backveined into the dyke. The latter continues as isolated boudins a few metres in size, which occur up to hundreds of metres apart along two parallel imaginary lines approximately along strike. The two trains of boudins are likely to belong to only one dyke repeated laterally by folding. The dyke was not found in the orthogneisses and may have intruded the supracrustal sequence before they were emplaced, but apparently after the supracrustal pile had suffered some deformation. Its present occurrence as widely scattered, but unmistakable, boudins points to the very high strain suffered by the supracrustal pile.

\section{Metadiorite}

Three days were spent on reconnaissance mapping along the eastern coast of Nordlandet between $64^{\circ} 29^{\prime}$ and $64^{\circ} 35^{\prime} \mathrm{N}$ (south-west of the area shown on fig. 1). At the coast light grey tonalitic gneisses in amphibolite facies with isoclinally folded bands and enclaves of fine-grained intermediate to mafic amphibolite with occasional calc-silicate lenses are exposed. The rocks trend north-south with steep to vertical dips and represent a continuation of the widespread grey gneiss-amphibolite terrain between the head of Qugssuk and inner Fiskefjord mapped by Lauerma (1964) and in 1981 and 1983 by the author.

Half-way up the hillside, between 0.5 and $1.5 \mathrm{~km}$ from the coast, there is a rather well defined lithological change from light grey tonalitic gneiss to monotonous dark grey biotite- 
rich, medium-grained gneiss, presumably of quartz-dioritic to dioritic composition. This metadioritic gneiss, which extends westwards into central Nordlandet, first occurs as scattered bands and enclaves in the light grey coastal gneisses, but totally predominates west of a c. $200 \mathrm{~m}$ wide mixed boundary zone. The boundary was found to extend southward into the Qôrqut map sheet area and is exposed at sea level at Kingigtup taseraussa $\left(64^{\circ} 29^{\prime} \mathrm{N}\right.$, $51^{\circ} 29^{\prime} \mathrm{W}$ ). About $2 \mathrm{~km}$ from the coast the first tracts of dark brown metadioritic gneiss in granulite facies were encountered, and this rock extends further inland. The amphibolitegranulite facies boundaries are gradational, irregular, appear to be retrogressive, and occur within the well-defined, homogeneous metadiorite lithology.

The mafic gneisses at Nordlandet thus represent an early identifiable dioritic phase in the intrusion of the late Archaean orthogneisses, and it is not confined to Nordlandet. This confirmed the conclusions from mapping inland between Godthåbsfjord and Fiskefjord in 1983 (Garde, 1984).

\section{Grey gneiss, Taserssuaq tonalite and Qugssuk granite}

Light grey tonalitic gneisses predominate along the east coast of Qugssuk, which forms the approximate boundary between amphibolite facies rocks with evidence of former granulite facies to the west and rocks to the east where amphibolite facies metamorphic conditions were probably not exceeded.

Around Sarfánguit the light grey tonalitic gneisses give way to agmatitic polyphase gneisses including large components of both dioritic gneiss and granitic neosome (several phases of granite and pegmatite), the latter cross-cutting the gneisses at scales from centimetres to tens of metres. The granitic material increases by volume eastwards until it forms most of the outcrops east of a north-north-east trending line through the central part of the peninsula. Along the south coast of Ivnarssuaq and particularly Ivnarssuit there are spectacular cliff faces with strongly agmatised amphibolite and grey gneiss swimming in a granitic (sensu stricto) matrix. In spite of the lack of continuous outcrop across the Narssarssuaq valley there can be little doubt that the granite at Ivnarssuaq is the south-eastern continuation of the Qugssuk granite (Garde et al., in press). The granite is always younger than the gneiss (and the Taserssuaq tonalite, see below) where relations can be established, but has suffered some deformation. It seems to have been intruded contemporaneously with a late deformation event which resulted in upright folds, tight to isoclinal, with amplitudes of the order of 1-2 km. The granite is sometimes subject to metre-scale folding related to this episode and sometimes intrudes the same folds along vertical axial planes trending c. $40^{\circ}$.

Most of the rocks at the Ivnarssuaq peninsula were included in the Taserssuaq granodiorite during reconnaissance mapping in the 1970s (Allaart et al., 1977), including the areas now known to be underlain by Qugssuk granite. However on the peninsula the Taserssuaq rocks are limited to the south-eastern and eastern parts. It is often strongly sheared along the Ataneq fault but still recognisable, being very homogeneous, coarser and more mafic than the Qugssuk granite, and characterised by 1-2 cm large feldspar porphyroblasts. Anatectic relations between Taserssuaq tonalite and Qugssuk granite as described by Garde et al. (in press) were rarely observed on the Ivnarssuaq peninsula, whereas the former is frequently intruded by the latter, in the same manner as the grey gneisses.

Associated with the Taserssuaq tonalite there are enclaves, trains of agmatitic inclusions and massive xenolithic bodies of metagabbro-leucogabbro up to a couple of kilometres in 
Fig. 2. Geological correlation across the Ataneq fault north-east of Ivnarssuit. See fig. 1 for location.

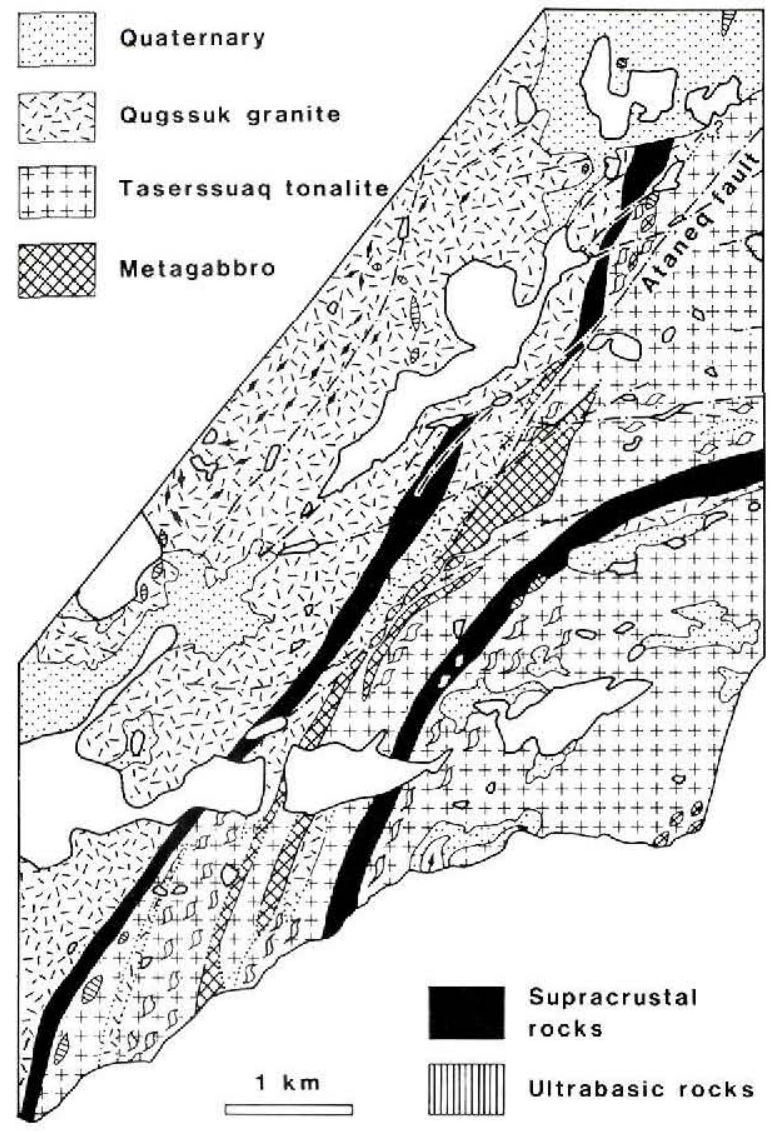

size. The metagabbros are medium grained and homogeneous at outcrop scale, but judged from their colour index their composition spans from (ultra)mafic to intermediate. The metagabbros are located within or at the margins of Taserssuaq tonalite outcrops, and field relations indicate that they predate the tonalite but were emplaced together with it, perhaps in a semi-crystalline state. The genetic relations between the metagabbros and Taserssuaq tonalite are not well known. Similar metagabbro-leucogabbro bodies occur in the Taserssuaq pluton further east, and they may be derived from an evolving magma system culminating with the Taserssuaq tonalite (Brewer et al., 1984).

\section{Ataneq fault}

The area south-east of Narssarssuaq is crossed by the Ataneq fault (fig. 2). The rocks in this area are strongly deformed in a $c .4 \mathrm{~km}$ wide zone of ductile shear which trends northeast, and the rocks possess a well-developed biotite and/or hornblende foliation, except leucocratic members of the Ougssuk granite (devoid of mafic minerals) which are compact, fine grained and white, locally almost glassy. The Ataneq fault itself consists of several subvertical dextral slip surfaces in the central part of the shear zone. It was possible to trace vertical 
north-north-east trending amphibolite, metagabbro, tonalite and granite layers from the south into the north-east trending shear zone, across the faults and out again on the northern side back into the north-north-east trend. The total dextral strike-slip displacement across this part of the Ataneq shear zone and fault is only 4-5 km, and the actual slip along the fault surfaces is about $1 \mathrm{~km}$. There are no indications of any significant vertical component. The displacement is comparable to a Proterozoic dextral strike-slip displacement of $4 \mathrm{~km}$ on the Ataneq fault east of Ilulialik, which was suggested by Brewer et al. (1984) on the basis of an offset MD dyke.

The Ataneq and Fiskefjord faults are both part of a large conjugate Proterozoic fault system with two fault directions, north-east and west-north-west, resulting from east-west compression, of which the former direction is by far the more prominent. Whereas the Fiskefjord fault seems to be entirely caused by (at the present level of exposure) brittle Proterozoic deformation, it is known that the Ataneq fault has had a prolonged history dating back to the Archaean (Nutman, in press; Brewer et al., 1984). The latter authors suggest that the Ataneq fault originated as a thrust like other thrusts in the Ivisartoq region, and was later reactivated as part of the conjugate system. No evidence of early thrusting was found in the Ivnarssuaq area, but it is likely that the shearing and even the development of the latest generation of large-scale folds at Ivnarssuaq were manifestations of a long-lived east-west stress system, operating at intervals during late Archaean and Proterozoic times.

\section{Geological correlation across outer Godthåbsfjord}

The presence of retrograde tonalitic gneiss along the coast of Nordlandet at Kingigtup taseraussa and the small displacement on the Ataneq fault at Ivnarssuaq indicate that the geological contrast across outer Godthåbsfjord is not due to a major fault. It is probably best explained by a gradual retrogressive transition from granulite to amphibolite facies of the same nature as that across the head of Qugssuk, and a moderate relative uplift and thrusting of Nordlandet in an easterly direction caused by late Archaean/early Proterozoic east-west compressive stress, exposing a deeper crustal level at Nordlandet than to the south-east. Structural evidence for the latter event was found both at Nordlandet and on Store Malene but is outside the scope of this report.

\section{References}

Allaart, J. H., Jensen, S. B., McGregor, V. R. \& Walton, B. J. 1977: Reconnaissance mapping for the 1:500 000 map sheet in the Godthåb-Isua region, southern West Greenland. Rapp. Grønlands geol. Unders. 85, 50-54.

Brewer, M., Chadwick, B., Coe, K. \& Park, J. F. W. 1984: Further field observations in the Ivisartoq region of southern West Greenland. Rapp. Grønlands geol. Unders. 120, 55-67.

Garde, A. A. 1984: Field work between Fiskefjord and Godthåbsfjord, southern West Greenland. Rapp. Grønlands geol. Unders. 120, 45-50.

Garde, A. A., Larsen, O. \& Nutman, A. P. in press: Dating of late Archaean crustal mobilisation north of Qugssuk, Godthåbsfjord, southern West Greenland. Rapp. Grønlands geol. Unders. 128.

Lauerma, R. 1964: On the structure and petrography of the Ipernat dome, western Greenland. Bull. Grønlands geol. Unders. 46, 88 pp.

Nutman, A. P. in press: The early Archaean to Proterozoic geology of the Isukasia area, southern West Greenland. Bull. Grønlands geol. Unders. 154. 